\title{
OPPORTUNITIES FOR LATVIAN EXPORT OF MEDICAL SERVICES
}

\author{
Tamāra Grizāne ${ }^{1}$, Ingūna Jurgelāne ${ }^{2}$, Līga Jankova ${ }^{3}$, Aija Sannikova ${ }^{4}$ \\ ${ }^{1}$ Turiba University, Latvia \\ ${ }^{2}$ Riga Technical University, Latvia \\ ${ }^{3}$ Latvia University of Life Sciences and Technologies, Latvia \\ ${ }^{4}$ University of Economics and Culture, Latvia \\ tamara.grizane@inbox.lv
}

\begin{abstract}
Historical and current development tendencies of medical tourism in Latvia, economic and geographical accessibility of Latvia for medical tourists, the high acknowledgement by the European Parliament Committee on Transport and Tourism on the potential of Latvia of becoming one of the largest medical tourism destination points, allow us to evaluate the potential for medical tourism among the priority countries for Latvia. Unfortunately, the lack of further analysis of potential limits the development of medical tourism strategy and monitoring. The research goal: determination of export potential of medical tourism services in the priority countries for Latvia. The research showed that there is a potential in every of the given countries: in Norway - rehabilitation and insert of acrylic implants; in Sweden - endovenous laser surgery and eyelid surgery; in Finland - rehabilitation and breast enlargement; in Ireland - rehabilitation and eyelid surgery; in Great Britain - rehabilitation and eyelid surgery. Results of the SWOT analysis indicated that in order to reach the export goals the existing drawbacks to the provision of medical tourism services in Latvia have to be averted while amplifying the use of the comparative advantages of Latvia.
\end{abstract}

Key words: medical tourism, medical tourism services, export.

\section{Introduction}

According to the document produced by the Ministry of Economics of Latvia 'Guidelines of Latvian Tourism Development for 2014 - 2020', Latvia has chosen the medical tourism (MT) as one of its sustainable tourism development priorities. It is believed that the MT includes health improvement procedures (Carrera \& Lunt, 2010; LR MK, 2014) and travelling with an aim of improving one's health (Bookman \& Bookman, 2007). However, from economic perspective, MT can be viewed as a more beneficial service because of the price advantages (Edelheith, 2008). The research for TRAN Committee - 'Health tourism in the EU: a general investigation', carried out by the European Parliament Committee on Transport and Tourism in 2017 indicated that Latvia can become one of the largest international medical tourism destinations. This export niche is not only indicated by the historical tendencies of the Latvia medical tourism, but also by the fact that Latvia is accessible to medical tourists both geographically and economically, as well as because of the number of available specialists and the high quality of provided services(Mainil et al., 2017). Until now the export capabilities of the MT in the priority countries of Latvia (further - priority countries), such as, Great Britain (GB), Irland (IE), Finland (FI), Norway (NO) and Sweden (SE) have not been analyzed, thus limiting the development of tourism development strategy and monitoring (TAVA, 2010).

The research aim: Evaluation of medical tourism export capabilities in the priority countries of Latvia.

The research tasks: 1) to study theoretical aspects of medical tourism; 2) determine and analyze the historical and current development tendencies of medical tourism in Latvia; 3) carry out the analysis of medical tourism market in the priority countries for Latvia: Great Britain, Irland, Finland, Norway and Sweden; 3) carry out SWOT analysis of themedical tourism in Latvia.

The object of the research is the export of medical tourism services of Latvia.

\section{Materials and Methods}

The main research methods applied: monographic, descriptive, logical, comparative analysis, analysis and synthesis, induction and deduction. Analysis of literature, e.g. legal regulations, research papers, academic papers, other scientific literature, and internet resources, etc., was conducted to prepare this scientific paper. The SWOT analysis was carried out in order to determine the conditions for successful reaching of the export capabilities of Latvia medical tourism services (MTS).

\section{Theoretical aspects of medical tourism}

In different literature sources the offered explanation of the MT includes both similarities as well as differences. Similarities include the movement of people in between geographical locations in order to receive medical services (Lunt et al., 2016; Majeed et al., 2017; Medical Tourism Association, 2017). Authors underline that the medical services may be available in the country of residence, though undermined by the wait in long queues and by high service price (Li \& Cui, 2014). The differences in the explanation of the term are: economic acitivity, which defines the joint medical and tourism industries as set 
on the goal of receiving and offering medical services, or as ensuring of continuous growth of the multibillion dollar industry which makes countries compete in the area of medical standards and offered service quality, while maintaining the lowest possible price for the offered medical services (Bookman, 2015; Sandberg, 2017).

The term of the subject of the medical tourism 'medical tourist' (Mt) is likewise debatable and can be explained - as a person which is travelling to different region or country with a goal of receiving more accessible, higher quality and cheaper services. Often people choose to visit foreign countries in order to receive medical services which are not available in their country of residence, for instance, euthanasia (i.e. assisted suicide) (Cohen, 2015).

In the context of Europe, the protection of Mt rights under the Directive 2011/24/EU allows for receiving safe, democratic medical services. Meanwhile, the research carried out by the European Public Health Alliance (EPHA) indicates the lack of accessibility, for instance, due to difference in the level of salary among the EU memberstates, (Legido-Quigley et al., 2011; European Public Health Aliance, 2015). Authors conclude that the MTS can be defined as services with the aim of improving health, and that despite the numerous existing obstacles it is still a very profitable industry.

\section{Retrospective in the medical tourism history}

For the comprehensibility of the medical tourism history, the authors divided the observed time line in the following stages: (1) time before Christ (BC) (2) medieval time; (3) renaissance and post-renaissance period (4) the 20th century, and (5) the 21 st century. In 4000 BC Ancient Shumeri created the first known health recreation complex with hot baths and temples (Benzier, 2013).The Bronze Age evidence shows that travelling with the aim of health improvement was taking place in the current day territories of Germany, France and Switzerland (Health Tourism, 2017). The roots of MT can be traced to the ancient Greek pilgrims who travelled to the Mediterranian region in the Epidauria Saronikas bay (the small Mediterranean town of Epidauria in the Saronic Gulf). It is believed that the Asclepia Temples was the first registered travel destination of such kind (Balaban \& Marano, 2010). After the collapse of the Roman Empire, in the medieval time, the region of Asia became the leading attraction point for medical tourism. The meaning of temples was decreasing while their place was taken by the first hospitals in which travelers were offered medical treatment. However, the renaissance (the 14th - 17th centuries) is believed to be the development period of MT and during that time the term 'spa' appeared and was used describing the facilities which were more widely available (the 16th century) throughout the Europe (Li \& Ciu, 2016).

MT is one of the phenomena of the 21 st century that has attracted both the attention of state and private sector. As a result of globalization, MT has vast opportunities to seek cheaper, more accessible and higher quality services with a possibly shorter waiting period (Carrera \& Bridges, 2006; Bakuczb, 2017).

The authors conclude that the history of MT show that people have gone travelling with the aim of health improvement, because the desired medical service has not been available in the country of residence.

\section{The current global state of medical tourism}

Already in 2010 Balaban and Marano predicted a sharp yearly rise of MT globally from 600,000 to 750,000 (Balaban \& Marano, 2010). However, the reality of the MT field exceeded hopes, with trends in 2017 showing that around $3-4 \%$ of world citizens will use international health care and treatment in the next 10 years. Demographic change can be mentioned as the main reason, especially the ageing of many countries' citizens. Already in 2017 the market had reached 439 billion US dollars, but the predicted speed of increase is $25 \%$ larger than in 2016 . The medical travel market might increase up to 3 trillion US dollars by 2025 (Healthcare Markets, n.d.).

The top fields of the world's MTS are: 1) cosmetic surgery; (2) dentistry (general, restorative, cosmetic); (3) cardiovascular diseases (angioplasty, CABG, transplants); (4) orthopedics (joint and spine; sports medicine); (5) cancer (often high-acuity or last resort); (6) reproductive (fertility, IVF, women's health); (7) weight loss (LAP-BAND, gastric bypass); (8) scans, tests, health screenings and second opinions (Healthy Travel Media, 2011).

Currently 28 countries in North America, South America, Europe and Asia are occupied with the international trade of the MTS available in their countries. 375 medical institutions in 47 countries have registered themselves as MTS providers. It is likely that the popularity of MT in the 21 st century will continue to rise, as the demand for MTS in the Western countries exceeds the medical service offer (Li, \& Ciu, 2014). Certainly, one of the MT trends today is the change in its structure, compared to what the world knew before. This trend is determined by market forces that take place outside the organized heath care system's regulations and control. It increases the impact of health care in developed and developing countries around the globe (Horowitz, Rosensweig, \& Jones, 2007). The fact that this sphere is not regulated allows entrepreneurs giving services or the service intermediaries to satisfy all clients' wishes, if it is in their interests. However, the lack of regulation creates not only opportunities to be attractive in the eyes 
of potential clients, but also threaten the quality of services. This trend is stressed by David A. Reisman (2010), expressing the risk of MTS being perceived as usual trade services and that choices may be taken merely driven by the price factor, not monitoring other quality factors. All parties involved in the health care have an undeniable need to become familiar with the MT and understand the economic, social, political, and medical forces that form this phenomenon (Horowitz, Rosensweig, \& Jones, 2007).

\section{Research methodology}

Creation of a world level health treatment destination for MTS export purposes is a difficult task. The analysis of scientific research of variety of authors showed that its creation depends on the following factors: (1) political oversight and social stability; (2) investments of the private and public funds in the health infrastructure; (3) tourism infrastructure (4) international flow of patients; (5) compliance with the international accreditation, which ensures oversight of quality and results; (6) price, i.e. possible savings for alternative purchase of medical procedures; (7) long-lasting outstanding clinical reputation; (8) health sector innovation and achievement history; (9) the successful implementation of good practice and modern medical technologies; (10) availability of internationally educated medical personnel. One of the main criteria for comparative analysis of countries is based on the service availability - how long the potential client has to wait in order to receive MTS, available bed places per 1000 inhabitants, insurance, travel and time costs. In order to compare the price categories in the most objective way, the authors compared the average prices (from lowest to highest) of the private clinics (in Latvia and other countries), including each economic branch (MTS criteria group), and for at least 3 services. In dentistry the following services were analyzed: (1) visits; (2) tooth hygiene; (3) tooth removal; (4) tooth fillings; (5) dental crowns; (6) acrylic implants. In plastic surgery: (1) upper eye-lid plastic; (2) breast enlargement; (3) stomach lipo-suction. Flebology prices were compared for the following services: (1) foam sclerotherapy (for one leg); (2) biological methods with biologic glue (venaseal, for one leg); (3) endovenous laser surgery (EVLT) (for one leg). Cancer diagnostics: (1) melanoma diagnostics; (2) breast cancer diagnostics; (4) prostate cancer diagnostics. Rehabilitation prices: (1) health massage (10x); (2) balneotherapy (1 x); and (3) a ten day course - medical rehabilitation (in summer). Prices were recalculated to Euro from the local currencies, based on the Bank of Latvia currency trade rate for November 29, 2017.

Price and offer analysis included the following criteria: (1) service costs in the country of origin;
(2) service costs in Latvia; (3) residence costs in a hotel in Latvia; (4) transport costs from the country of residence to Latvia; (5) average time in queue and the time spent while traveling to Latvia. Taking into account the above mentioned, the comparison was carried out based on an original method created by the authors of this research, for possible savings for the patient if one would choose MTS in Latvia based on the following equation:

$$
A j=\frac{\sum_{i=1}^{n} W_{i}}{n}+\frac{\sum_{i=1}^{m} H i}{m}+\frac{\sum_{i=1}^{k} R i}{k},
$$

where $A j$ - priority country full costs in Latvia were determined as MTS criteria group in Latvia; $\mathrm{Wi}-\mathrm{i}$ cost of service; $\mathrm{Hi}$ - costs of hotel, $\mathrm{Ri}$ - travel costs from country of origin to Latvia; $\mathrm{n}, \mathrm{m}, \mathrm{k}$ - complementary number of criteria.

$$
B j=\frac{\sum_{i=1}^{n} W_{i}}{n}+\frac{\sum_{i=1}^{m} H i}{m},
$$

where $B j$ - the full costs are based on the full costs of MTS criteria group in priority country; $\mathrm{Wi}-\mathrm{i}$ price of service; $\mathrm{Hi}$ - costs of hotels; $\mathrm{n}, \mathrm{m}$ - number of complementary criteria.

$$
\mathrm{Sj}=\frac{A j}{B j} * 100-100(\%)
$$

where $\mathrm{S} j$ - savings of the patient (\%) when choosing MTS in Latvia; $A j$ - priority country full costs in Latvia were determined as MTS criteria group in Latvia; $B j$ - the full costs are based on the full costs of MTS criteria group in priority country.

By determining the MTS export possibilities the authors analyzed those MTS with whom Latvia has comparative (price, availability, historical experience) advantages in comparison with other countries.

\section{Medical tourism services in Latvia: history and currentsituation}

The use of health improvement resources in Latvia can be dated back to the second half of the 18th century, when the nobles of the Dutchy of Courland for health improvement reasons used spring waters and sludge (Kemeri National Park Foundation, 2018). In the towns of Latvia, Liepaja and Cēsis, as far back as in the 19th century the Tsars of Russia and other nobles visited the sites for health improvement reasons, used swimming resorts and health improving creeks (Liepaja region tourism information bureau, 2015). The owner of Baldone, baron fon Korf received 
from the Russian Tsar Catherina II a decree allowing him to create a sulfurwater treatment facility, and already in 1796 the resort was established, but in 1838 the Kemeru resort was opened (Kleinbergs, 1928; Grants et al., 2014). In the end of the 19th century and beginning of the 20th century many travelers arrived from other parts of Russia, as well as other countries. Until 1914 in Kemeru resort the number of treated persons reached as many as 8300 per year (Bērziņš, 1978). The number of visitors attending sulfur bath resort in Kemeri during a single week in the summer of 1928 reached 2410. Visitors from Lithuania, Finland, Sweden, Poland etc., represented different social levels - from janitors to factory workers that were treated for neurological, digestive, gynecological diseases, as well as received the weight loss treatment. Heart, asthmatic diseases were treated in a specialized Birinu sanatorium established in 1925, while tuberculosis and other respiratory problems were treated in Tervete sanatorium. The availability of awide variety of treatment and tourism infrastructure, good bus and train connections, possibility to rent a car, take part in excursions and listen to symphonic music should be noted (Lībietis, 1928; 1938). During the German occupation in the WW II the treatment facilities and technical means of Kemeru resort were dismantled and taken away while the buildings were left intact. From 1945 a slow renewal of the resort took place. In the Soviet Union the Kemeri resort was a well-known and popular resort. Altogether six standalone facilities were built in the resort. In 1967 a new facility was built in Jaunkemeri, which was included in the Kemeri resort system. In 1971 Kemeri was given the state-level resort status of the whole Soviet Union which allowed toreceive additional financial aid from Moscow, as well as an increase of the overall number of employed personnel and construction of further extensions. Unfortunately, nowadays in Kemeri resort there is no functional facility. In Jaunkemeri only the rehabilitation resort "Jaunkemeri" and the resort "Jantarnij bereg", owned by the Chancellery of President of Russian Federation, are in operation. This centre of rehabilitation continues the use of Kemeri biologically active resources - sulphur water, bromium mineralwater and natural peat sludge (Grants et al., 2014).

The authors concluded that historically Latvia has been a health tourism destination due to the fact that during the hay days of the resorts the visitors were sent to these facilities on basis of the doctor's prescription, and were treated to full-fledged health treatment procedures. However, nowadays it is important not to mix health tourism with MT, although in Latvian a stand-alone definition for the term is not available and other instances describe MT as a part of health tourism. Thus, the beginning of MT can be traced back to the post-renewal of independence in 1990ies, when in statistics those visitors which were visiting the country with the clear purpose of health improvement through purchase of MTS, were placed into this segment. However, such segmentation and the lack of statistical observations seriously influenced the development of the present day MT in Latvia.

After the economic crisis of 2009, a more active approach to tourist attraction was started, which resulted in the creation of the private clinic alliance 'Baltic Care.' Its purpose was to attract foreign clients by combining the best known private clinics of Latvia and specialists in one place. The alliance includes 16 clinics which ensure such services as plastic surgery, vein treatment, dermatology, treatment of infertility, dentistry, traumatology, diagnostics, oncology and other services (Baltic Care, 2017).

Based on the data of the Health Inspectorate of Latvia, in 2017 there were 44 health facilities registered as MTS providers. The largest part of them were located in Riga, Jurmala and Sigulda, respectively $62 \%, 14 \%$ and $5 \%$, but in Ludza, Priekule, Adazi county, Liepaja, Daugavpils, Krimulda, Balvi and Rezekne - 2\% (LR VMVI, 2017).

'Baltic Care' ensures the following MTS (respective number of facilities): (1) flebology - 7; (2) proctology - 4; (3) ceratoplastics -2 ; (4) treatment of fertility services $-2 ;(5)$ atmology $-2 ;(6)$ eyelid plastics -10 ; (7) oncology diagnostics -6 ; (8) cyberknife services -1 ; (9) dentistry - 12; (10) melanoma treatment - 3; (11) prostate cancer treatment - 4; (12) plastic surgery - 9; (13) rehabilitation services - 10; (14) gastric bypass services are offered by two institutions (Baltic Care, 2017).

\section{Results and Discussion}

The health insurance system (Table 1) ensures that all inhabitants frompriority countries should have state paid health insurance, however, lately inhabitants have been purchasing additional private insurance. Currently as many as $6 \%$ of inhabitants have additional health insurance. The insurance does not cover dentistry services for the grown-ups, cosmetic, vision procedures and diagnosis. Patients have to co-finance almost every service up to $14 \%$ and every treatment has the highest price margin (The Commonwealth Fund, 2017). If the insurance does not cover services or covers them partly then the Mt, according to Milsteine \& Smith (2006), chooses a service in a different country.

The availability of beds in priority countries for Latvia, according to the 2015 data, show some of the worst results in Europe (Table 1), Sweden being in the worst situation (OECD, 2017). Patients have to wait in queues also for paid services, according to the data for the year 2016. Euro Health Consumer index is a 
Priority countries: Summary of Insurance Types, Free beds per 1000 inhabitants and

Table 1 Maximum waiting time

\begin{tabular}{|l|l|l|l|l|l|l|}
\hline \multicolumn{1}{|c|}{ Criteria } & \multicolumn{1}{c|}{ LV } & \multicolumn{1}{c|}{ GB } & \multicolumn{1}{c|}{ IE } & \multicolumn{1}{c|}{ FI } & \multicolumn{1}{c|}{ NO } & \multicolumn{1}{c|}{ SE } \\
\hline Insurance Type & private & $\begin{array}{l}\text { state/ } \\
\text { private }\end{array}$ & $\begin{array}{l}\text { state/ } \\
\text { private }\end{array}$ & $\begin{array}{l}\text { state/ } \\
\text { private }\end{array}$ & $\begin{array}{l}\text { state/ } \\
\text { private }\end{array}$ & $\begin{array}{l}\text { state/ } \\
\text { private }\end{array}$ \\
\hline Free beds per 1000 inhabitants & 5.7 & 2.6 & 3.0 & 4.4 & 3.8 & 2.4 \\
\hline Maximum waiting time & not specified & 4 months & 9 months & 6 months & Individuāli & 3 months \\
\hline
\end{tabular}

topical problem in these countries (Health consumer Powerhouse, 2016). Long queues for services have stimulated the creation and purchase of private health insurance, which financially is not available to every citizen. Therefore, many citizens are investigating health service opportunities outside of their own country borders in order to receive the needed medical services, as it has been underlined by Michael, et al. (2007).

When calculating the possible savings (in percentage) $\mathrm{Sj}$, if $\mathrm{Mt}$ has chosen MTS in Latvia (Fig.1), it was determined that the Norwegian patients hold the highest export potential. The only service which is not financially feasible in Latvia for them is the melanoma diagnostics, which is muchcheaper in Norway, in comparison. Financially the most economical is to carry out rehabilitation course, which in total allows to save $€ 1303,87$. In the meantime, for Mts from Sweden it is far more economical to carry out cosmetic procedures - endovenous laser surgery procedure, which in total allows to save $€ 1504,69$, while just the eyelid surgery holds $€ 896,26$ savings. In the meantime, for patients from Finland the only service which is not feasible to be carried out in Latvia is the melanoma diagnostics, but breast enlargement procedures in Latvia in comparison are $72 \%$ cheaper. The potential patients from Ireland would not choose Latvia to perform acrylic implant injection procedures, as well as melanoma diagnostics, because in Ireland the overall costs are lower than those in Latvia, combined with the transport and living costs. Financially the most profitable for them is to carry out rehabilitation course which allows for a $€ 3337,40$ savings, as well as eyelid surgery procedures, which allow to save $€ 2677,40$. Misunderstanding the fact that geographically the distance from Ireland and Great Britain to Latvia is similar, the Mt from Great Britain would get the largest savings from purchasing services in Latvia by choosing arehabilitation course totalling at $€ 4967,00$, or eyelid surgery $-€ 2203,16$ in savings.

When summarizing the information about the price and full service comparison (Fig. 1), it can be concluded that Latvia has MTS export potential in the following countries and MTS: (1) Norway - rehabilitation and acrylic implants; (2) Sweden - endovenous laser surgery and eyelid surgery; (3) Finland - rehabilitation and breast cosmetic surgery; (4) Ireland - rehabilitation and eyelid surgery and (5) Great Britain - rehabilitation and eyelid surgery.

In order to successfully fulfill MTS export possibilities, the authors carried out MT SWOT analysis of Latvia. The strong traits included: (1) the number of available medical institutions and the quality personnel; (2) diagnostics of such medical sub-categories as plastic surgery, rehabilitation, oncology, flebology, high level professional output; (3) competitive price levels in MTS in comparison

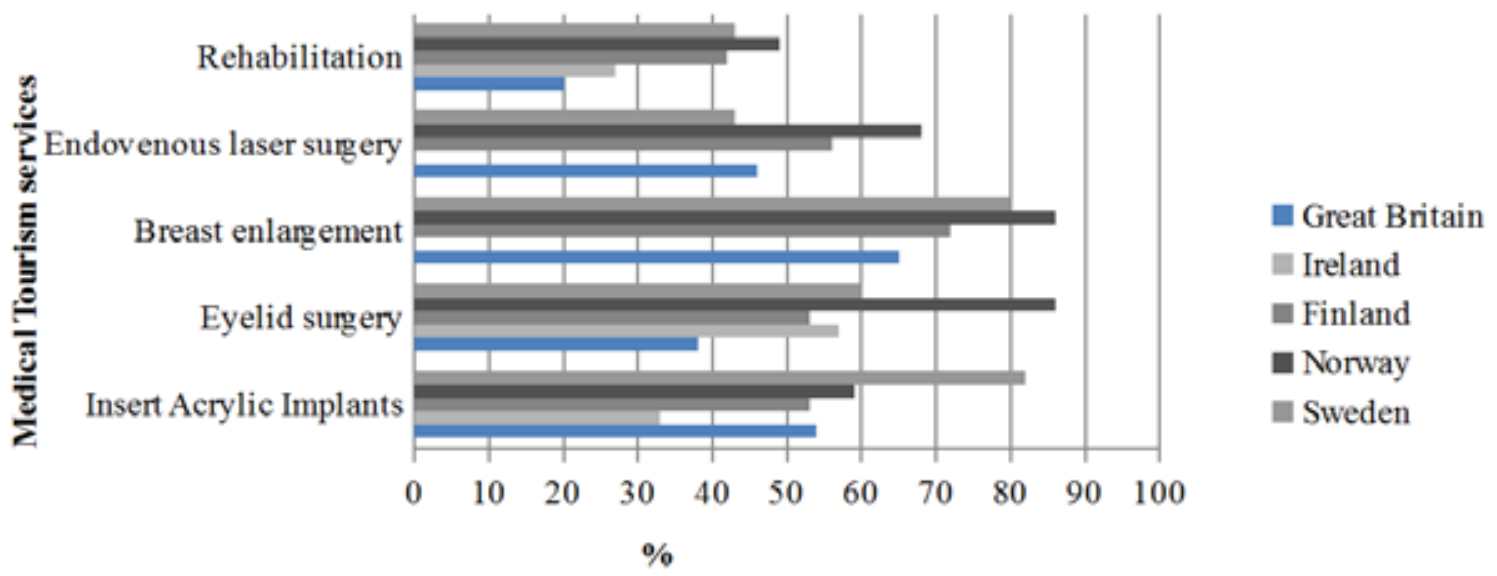

Figure 1. Percentage of possible gains from choosing medical tourism services in Latvia. 
with priority countries; (4) non-limited access to paid services offered by private clinics. The weak points included: (1) lack of legal regulation; (2) lack of communication with foreign Mts about the licences of private clinics and other quality aspects; (3) lack of information about the possibilities to cover MTS costs in other countries. Some of the threats for MTS included: (1) language barrier; (2) with the increase and spread of MT the market developments increase competition with the service providers from the third countries; (3) the damage created to the MT industry by cheaper and less qualified service providers; (4) changes of law, larger financing for medical capacity in the priority countries; (5) the overall knowledge of all aspects connected to MT; (6) an increase of price, the reduction of competitiveness. As a result of the MT SWOT, the authors identified multiple possibilities: (1) medical associations should create the trustworthy service provider lists; (2) increase and development of MT market in the EU; (3) creation of a common connected MT legal regulation; (4) cooperation possibilities with the tour operators; (5) the geographical advantage of Latvia and use of possibilities by participation in the EU; (6) leading of competitive MTS in export markets; (7) carrying out monitoring of tendencies in the target markets, in order to adapt and support MTS export capabilities.

\section{Conclusions}

1. Since the second half of the 18th century Latvia has been a destination of health tourists owing to its provided health effects from usingspring waters and sludge. The development of resorts attracted Mts looking for neurological,digestive, gynecological, heart, tuberculosis and respiratory system disease treatment as well as for weight management - it was a historical basis on which the present day MT of Latvia was built.

2. The beginnings of the MT in Latvia can be traced back to the 1990ies when in statistics a segmentation of foreign tourists arriving with the aim of receiving health improvement services was carried out. Nonetheless, the segmentation of statistics and the lack of thrustworthy statistics has influenced the present MT development, especially because Latvia has to develop the MT service export possibilities.

3. Latvia should use the MT service export possibilities in the priority countries by offering certain services to specific countries: to Norway - rehabilitation and insertion of acrylic implants; to Sweden - endovenous laser surgery and eyelid surgery; to Finland - rehabilitation and breast enlargement; to Ireland - rehabilitation and eyelid surgery and Great Britain - rehabilitation and eyelid surgery.

4. In order to successfully fulfill the practical MT export possibilities, the MT of Latvia has to avert the problems in the legal regulation eliminate drawbacks in communication with the foreign medical tourists about the licences of the private clinics; to ensure the availability of information about the possibilities to receive MT services; as well as to use the existing advantages of the medical tourism of Latvia.

\section{References}

1. Bakuczb, M., Hoz-Correra, A., \& Muñoz-Leiva, F. (2017). Past themes and future trends in medical tourism research: A co-word analysis. Tourism Management Journal, 65, 200-211. DOI: 10.1016/j. tourman.2017.10.001.

2. Balaban, V., \& Marano, C. (2010, March). Medical tourism research: A systematic review [Abstract]. International Journal of Infectious Diseases, 14(1), e135-e135. DOI: 10.1016/j.ijid.2010.02.1784.

3. Baltic Care. (2017). Klïnikas. (Clinic). Retrieved February 12, 2018, from: http://www.balticcare.eu/lv/ klinikas-1/. (in Latvian).

4. Benzier, D. (2013). Historical Background of Medical Tourism. Medical Tourism website. Retrieved February 12, 2018, from: http:/www.medicaltourism.com/blog/historical-background-of-medicaltourism-2/.

5. Bērziņš, J. (1978). Rīgas iedzìvotāju atpūtas vietas II Rīga 1860-1917. (Recreation places of Riga's inhabitants' II Riga, 1860-1917) Riga: Zinatne. (in Latvian).

6. Bookman, M. (2015). Medical Tourism in Developing Countries. 6th edition. United Kongdom: Palgrave Macmillan.

7. Bookman, M., \& Bookman, K. (2007). Medical Tourism in Developing Countries. Basingstoke: Palgrave Macmillan.

8. Carrera, P., \& Bridges, J. (2006). Globalization and healthcare: Understanding health and medical tourism. Expert Review Pharmacoeconomics Outcomes Research, 6, 447-454. DOI: 10.1586/14737167.6.4.447.

9. Cohen, I. (2015). Patients with Passports: Medical Tourism, Law, and Ethics. Oxford: Oxford University Press.

10. Edelheit, J. (2008). Defining medical tourism or not? Medical Tourism Magazine, 5, 9-10 DOI: 10.5267/j. msl.2014.7.021. 
11. European Public Health Alliance. (2015). Closing Gaps, Stimulating Health Equty: EPHA Report un the Implementation of the Cross-border Healthcare Directive. Brussels. Retrieved February 15, 2018, from: http://v2.epha.org/IMG/pdf/EPHA_Report_Cross_border_Healthcare_final_Oct15.pdf.

12. Grants, P., Bukovska, N., Stepiņa, D., \& Straube, A. (2014). Tematiskais plānojums „,Kemeru attīstības vizija”. (Thematic Planning of Kemeri Development Vision) Retrieved February 12, 2018, from: https:// www.jurmala.lv/docs/j14/x/j140243_KEMERU\%20VIZIJA.pdf. (in Latvian).

13. Health consumer Powerhouse. (2016). Euro Health Consumer Index 2016. Retrieved February 5, 2018, from: https://healthpowerhouse.com/files/EHCI_2016/EHCI_2016_report.pdf.

14. Healthcare Markets. (n.d.). Retrieved September 5, 2017, from International Medical Travel Journal (IMTJ) website, Retrieved February 5, 2018, from: https://www.imtj.com/resources/healthcare-markets/.

15. Health-Tourism.com (2012). The history of medical tourism. Health-Tourism.com website. Retrieved March 14, 2018, from: http://health-tourism.com/medical-tourism/history/.

16. Healthy Travel Media. (2011). Medical Tourism Statistics \& Facts. Patients Beyond Borders. Retrieved March 11, 2018, from: https://patientsbeyondborders.com/medical-tourism-statistics-facts.

17. Horowitz, M.D., Rosensweig, J.A., \& Jones, C.A. (2007). Medical Tourism: Globalization of the Healthcare Marketplace. MedGenMed, 9 (4), 33. Retrieved February 5, 2018, from: https://www.ncbi.nlm.nih.gov/ pmc/articles/PMC2234298/.

18. Kleinbergs, A. (1928). Baldones sēravoti. Latvijas Republika desmit pastāvēšanas gados. (Sulfur of Baldone. The Republic of Latvia for ten years) Rīga: Pētersona spiestuve. (in Latvian).

19. Kemeru nacionālā parka fonds. (Kemeri National Park Foundation) (2018). Kemeru kūrorta vēsture. (Spa History of Kemeri) Retrieved February 2, 2018, from http://www.kemerunacionalaisparks.lv/?r=135. (in Latvian).

20. Legido-Quigley, H., Passarani, I., Knai, C., Busse, R., Palm, W., \& Mckee, M. (2011). Cross-border healhtcare in the European Union: claritfying patients'rights. BMJ (Clinical research ed.), 342:d296. DOI: 10.1136/bmj.d296.

21. Li, H., \& Cui, W. (2014). History of medicine. Patients without borders. The historical changes of medical tourism. University of Westwrn Ontario Medical Journal (UWOMJ) 83(2), 22.

22. Liebietis, J. (1928). Kemeru sēravoti. Latvijas Republika desmit pastāvēšanas gados. (Sulfur of Kemeri. The Republic of Latvia for ten years) Rīga: Pētersona spiestuve. (in Latvian).

23. Liepājas reǵiona tūrisma informācijas birojs (2015). Türisma celvedis Liepāja un apkārtne. (Tourist guide for Liepaja and its surroundings) Liepāja: LRTIB. (in Latvian).

24. Lībietis, J. (1928, July). Ieradušos peldviesu saraksts. (Flower List of Emergency) Kemeru ziņas, 2, pp. 10-15. (in Latvian).

25. Lībietis, J. (1938, August). Kas jāzina un jāievēro Kemeru peldviesim? (Who needs to know and adhere to Kemer's bath-house?) Kemeru ziņas, 13, pp. 5-16. (in Latvian).

26. LR MK (Latvijas Republikas Ministru kabinets) (2014). “Latvijas tūrisma attīstības pamatnostādnes 2014.2020. gadam", (Quidelines of Latvian tourism development for 2014-2020) Riga: LR MK. (in Latvian).

27. LR VMVI (Latvijas Republikas Veselības ministrija Veselības Inspekcija). (2017). Ārstniecības iestādes, kas reǵistrējušās medicīnas tūrisma pakalpojumu sniegšanai. (Register of Medical institutions for the provision of medical tourism services) Retrieved February 12, 2018, from: http://www.vi.gov.lv/lv/ veselibas-aprupe/medicinas-turisms. (in Latvian).

28. Lunt, N., \& Carrera, P. (2010). Medical tourism: Assessing the evidence on treatment abroad. Maturitas, 66, 27-32. DOI: 10.1016/j.maturitas.2010.01.017.

29. Lunt, N., Horsfall, D., \& Hanefeld, J. (2016). Medical tourism: A snapshot of evidence on treatment abroad. Maturitas, 88, 37-44. DOI: 10.1016/j.maturitas.2010.01.017.

30. Mainil, T., Eijgelaar, E., Klijs, J., Nawijn, J., \& Peeters, P. (2017). Research for TRAN Committee Health tourism in the EU: a general investigation. European Parliament, Brussels: Policy Departament for Structural and Cohesion Policies. DOI: 10.2861/951520.

31. Majeed, S., Lu, C., \& Javed, T. (2017). The journey from an allopathic to natural treatment approach: A scoping review of medical tourism and health systems. European Journal of Integrative Medicine, 16, 22-32. DOI: 10.1016/j.eujim.2017.10.001.

32. Medical Tourism Association (2017). Medical Tourism FAQ's. Medical Tourism Association website [accessed 17 November 2017]. Retrieved February 2, 2018, from: http:/www.medicaltourismassociation. com/en/medical-tourism-faq-s.html.

33. Milstein, A., \& Smith, M. (2006). America's New Refugees - Seeking Affordable Surgery Offshore. The New England Journal of Medicine, 20. DOI: 10.1056/NEJMp068190. 
34. OECD (2017). Health at Glance, 2017: OECD Indicators, Paris: OECD Publishing. DOI: 10.1787/health glance-2017-en.

35. Reisman, D.A. (2010). Health Tourism: Social Welfare Through International Trade. Cheltenham: Edward Elgar Publishing Limited. Retrieved February 5, 2018, from: http:/www.uwomj.com/wp-content/ uploads/2014/12/v83no2_08.pdf.

36. Sandberg, D. (2017). Medical tourism: An emerging global healthcare industry. International Journal of Healthcare Management, 10 (4). DOI: 10.1080/20479700.2017.1296213.

37. TAVA (Tūrisma attīstības valsts aǵentūra) (Tourism Development State Agency) (2010). Latvijas tūrisma mārketinga stratēǵija 2010.-2015. gadam (Latvian tourism marketing strategy for 2010-2015) Riga: TAVA. (in Latvian).

38. The Commonwealth Fund (2017). The Norwegian Health Care System. Retrieved February 5, 2018, from: http://international.commonwealthfund.org/countries/norway/. 